\title{
Value Chain Innovations for Technology Transfer in Developing and Emerging Economies:
}

\author{
Conceptual Issues, Typology, and Policy Implications
}

\author{
Johan Swinnen and Rob Kuijpers \\ LICOS Centre for Institutions and Economic Performance \\ \& Department of Economics \\ KU Leuven, Belgium
}

Version: May 5, 2017

\begin{abstract}
The adoption of modern technologies in agriculture is crucial for improving productivity of poor farmers and poverty reduction. However, the adoption of modern technology has been disappointing. The role of value chains in technology adoption has been largely ignored so far, despite the dramatic transformation and spread of modern agri-food value chains. We argue that value chain organization and innovations can have an important impact on modern technology adoption, not just by downstream companies, but also by farmers. We discuss conceptual issues and provide an empirical typology of institutional innovations through which value chains can contribute to technology transfer to agriculture in developing and emerging countries.
\end{abstract}

The authors acknowledge research funding from the KU Leuven Methusalem Fund. The paper and the ideas expressed have benefited from comments and discussions with many colleagues, including Chris Barrett, Azeta Cungu, Liesbeth Dries, Hamish Gow, Bart Minten, Tom Reardon, Siemen van Berkum, Anneleen Vandeplas, Kristine Van Herck and David Zilberman. 


\section{Introduction}

The adoption of modern technologies in agriculture is widely believed to be important for improving the productivity and welfare of poor farmers in developing countries and a key ingredient for achieving poverty reduction, food security, rural development and structural transformation. However, the adoption of modern technology, including improved seeds and chemical fertilizer, has been disappointing, particularly in Africa (Evenson and Gollin 2003; Sheahan and Barrett 2014). The existing literature has tried to find explanations for this phenomenon by looking at various factors, including credit market imperfections (Feder et al. 1985), learning processes (e.g. Lambrecht et al. 2014), the quality of technological inputs (e.g. Bold et al. 2015), and profitability (e.g. Suri 2011).

The role of value chains in technology adoption has been largely ignored so far. This is an important gap in the literature, as agri-food value chains have transformed dramatically in the past decades (Reardon and Timmer 2007). Privatization and liberalization in the 1980s and 1990s induced important transitions in the institutional organization of value chains (Swinnen and Maertens 2007). This has coincided with a major influx of domestic and foreign direct investment in wholesaling, processing, and retailing and an increase in trade of high value agricultural products (Reardon et al. 2009). Urbanization and a global increase in consumer purchasing power resulted in an increased demand for high value and differentiated food products. Food safety and other quality aspects, such as convenience, diversity, branding, and the sustainability of the production process have become increasingly important.

While the extensive literature on technology adoption in agriculture is largely ignoring the role of value chains, the emerging value chain literature has paid relatively little attention to the role of technology transfer - with some exceptions (Kuijpers and Swinnen 2016). Most value chain studies focus on the determinants of farmer participation in modern value chains 
and the welfare implications for small farmers (e.g. Andersson et al. 2015; Maertens and Swinnen 2009; Michelson 2013; Reardon et al. 2009). We connect these two bodies of work and argue that (1) understanding the value chain in which a farmer is operating is key for understanding farmer technology adoption; and (2) understanding the role of technology is key in understanding the welfare effects of modern value chains.

Value chain organization and innovations can impact modern technology adoption, not just by downstream companies, but also by farmers. There is widespread evidence that food processors, marketing and retail companies in developing and emerging countries have upgraded their production processes using new technology in the past decades, often as a result of FDI and its horizontal spillover effects (Gow and Swinnen 1998; Reardon and Timmer 2014). This technological upgrading typically included a modernization of procurement systems for sourcing high quality raw material necessary to meet new consumer demands. One important aspect of this modernization process was the introduction of private standards (with corresponding traceability, auditing, and certification systems) to overcome information asymmetry, reduce transaction costs, and as a marketing tool (Swinnen 2007).

More stringent product or process standards often require investments in new technologies by farmers. ${ }^{1}$ Many studies have pointed at the challenges for small and poor farmers to satisfy these new requirements and at the risk of further marginalization. In this paper we argue that these standards and required investments may also stimulate innovation, technology transfer, and thus inclusion for these farmers. With imperfect (or non-existing) technology markets, various forms of value chain innovations have been introduced by up-

\footnotetext{
${ }^{1}$ Most standards, codified or not, either directly or indirectly prohibit the use of less costly technology (Swinnen et al. 2015). In fact many of the most visible standards for consumers directly prohibit or require the use of certain inputs. Examples of commonly prohibited inputs are child labor, chemical inputs (in accordance with organic farming standards), or battery cages in the production of poultry. Examples of commonly required inputs are milk cooling equipment for dairy farmers and traceability systems for farmers supplying supermarket channels. Additionally, standards often require certain practices. For example, GlobalGap certification requires Lychee farmers in Madagascar to use clean water for pre-harvest hand washing and to implement good picking and packaging practices for the transportation from the farm to the processing unit (Subervie and Vagneron 2013).
} 
and downstream companies to overcome the technology constraints experienced by farmers. Value chain innovations include various forms of vertical coordination, one of them being smallholder contracting with interlinked technology transfer.

This paper is related to a large theoretical and empirical literature on industrial organization and technology adoption in various fields of economics and management science. This includes seminal contributions on how companies and supply chains are organized to overcome transactions costs and technology constraints (e.g. Economides 1996; Gereffi et al. 2005; Klein et al. 1978; Milgrom and Roberts 1990; Williamson 1985) and to create a competitive advantage (e.g. Barney 1991; Dyer and Singh 1998; Hart and Tirole 1990); on contracting in developing countries (e.g. Bardhan 1989; Bell and Srinavasan 1989); on technology adoption in agriculture (e.g. Feder et al. 1985; Foster and Rosenzweig 2010); on international technology diffusion and vertical productivity spillovers from foreign direct investment and trade (e.g. Havranek and Irsova 2011; Keller 2004; Martins and Yang 2009); on modern food value chains, standards and sourcing (e.g. Reardon et al. 2003; Swinnen and Maertens 2007); and on the optimality of farm structures (e.g. Allen and Leuck 1998; Pollak 1985).

The contribution of our paper is in the first place empirical by documenting various types of technology transfer through value chain innovations in developing and emerging countries and relating them to conceptual models. To our knowledge this is the first article to systematically document these forms of technology transfer to agriculture and to provide a typology of the different value chain innovations ${ }^{2}$. In addition, in the second part of the paper we relate these different types of institutional innovations to several factors, such as tightening safety and quality standards, market imperfections, the value in the chain, and the

\footnotetext{
2 Throughout the paper we use the concept of "value chain innovations" as institutional designs and models that deviate from the standard value chain structure (as illustrated in Figure 1) that have been introduced to address specific objectives.
} 
nature of the technology investment (i.e. long versus short term and contract specificity). Finally, in the concluding section we draw on the combined empirical and conceptual insights to draw implications for policy.

The remainder of this paper is organized as follows. The next section introduces a conceptual framework that explains under which conditions private-initiated value chain technology transfer is expected to arise. In section 3 a variety of different value chain innovations for technology transfer are discussed and illustrated by empirical examples. Section 4 draws lessons from the empirical review and identifies key factors that played a role in value chain innovation for technology transfer. Section 5 concludes and draws some policy implications based on the theoretical and empirical insights, in particular, it discusses the role of governments in financing technology transfer programs.

\section{Some Conceptual Issues}

\subsection{Technology adoption with imperfect markets}

Consider a simple value chain (figure 1). With perfect markets, decisions to invest in technology are made independently at each stage of the chain. ${ }^{3}$ Demand and supply for a product with certain qualities determines the price level and thereby the incentive to invest in necessary technology. For example, a change in consumer demand for higher quality food will translate into a demand for high quality farm output and an incentive to upgrade technology by the farmer - and thus technology investments if profitable.

\footnotetext{
${ }^{3}$ Foster and Rosenzweig (2010) define technology as "the relationship between inputs and outputs" and the adoption of technology as "the use of new mappings between inputs and outputs, and the corresponding allocations of inputs that exploit the new mappings". In practical terms, technology adoption therefore refers to a transformation of the production process, which might result in enhanced efficiency (requiring less inputs to produce a given output) or in different product attributes (i.e. enhanced quality). This means, in practice, a firm can change its production technology by either combining its current inputs in a different way, or by applying new intermediate inputs (e.g. machinery) in the production process, with a certain technology embedded in it. A farmer for example, may change its production technology by combining his inputs (e.g. labor, land, seeds and water) in a different way, or by using a new intermediate input (e.g. high yielding seeds, chemical fertilizer, or pesticide) produced by an input supplier.
} 
Notice that parallel to the flow of goods and technology in the value chain there is a flow of finance (in the opposite direction). Access to finance (in the form of own liquidity or loans) at each stage of this chain is crucial as production costs and technology investments are carried in full by the individual actors. Moreover, costs of technology investment are incurred at the start of the production cycle, while payment occurs at the end, making access to capital essential to bridge this gap. This is especially the case in the agricultural sector where the duration of the production process is relatively long.

Note that next to the flow of finance there exists a flow information (not depicted by the figure). Information is important as farmers may need to adjust their production practices and technology when demand, government regulations, or consumer preferences change.

It is not difficult to see why technology adoption in a value chain organized by spotmarkets might not be working in the context of imperfect markets. Information transmission may be incomplete, such that farmers are unaware of the requirements for their products or the precise management practices that are required. It is also well known that financial markets are often not working well in developing and emerging countries and that rural credit markets are particularly problematic (Banerjee and Duflo 2014; Bardhan and Udry 1999). Poor farmers may simply not have the financial means to make the investment out of own savings and may not get loans from banks or other lenders. As a result, credit market imperfections and financial constraints will cause technology market imperfections, and the failure to adopt technology by farms.

Another reason for the farmer not to adopt the technology is uncertainty whether the technology investment will be rewarded. This can be due to the possibility of buyer holdup at the time of delivery (Klein et al. 1978; Gow and Swinnen 2001). Examples are late payments, renegotiation of prices at product delivery, or the absence of transparent and reliable quality evaluation procedures, which could lead to inappropriately rejecting produce. There is much 
empirical evidence that such holdup problems are important and widespread in agri-food value chains in developing and transition countries (e.g. Barrett et al. 2012; Cungu et al. 2008; Saenger et al. 2014).

\subsection{Value chain innovations to overcome technology market imperfections}

The failure to adopt the technology not only affects the farm but also all other agents in the chain. Technology companies have lower profits since they cannot sell their technology; processors do not get the raw material they need for producing consumer products; and consumers do not get the products they desire. All these agents have an incentive to make the farm adopt the technology.

Some of these agents may have better access to finance than the farms because they have more liquidity or have better access to credit, because they can draw on other commercial activities, or because they face lower transaction costs. The latter can be the case when the lead firm provides the technology to multiple suppliers (e.g. as part of an outgrower scheme) and benefits from economies of scale. Other agents in the value chain may also have better information on the required technology because they are closer to the final consumer and therefore might have better knowledge on consumer preferences (or better understanding of government regulations, domestically or abroad) and how different types of technology used by the supplier affect final demand. They may also have a better understanding of the complementarity of technologies along the chain (Milgrom and Roberts, 1990). ${ }^{4}$

These agents can then consider whether it is profitable to set up different types of exchange systems (rather than the spot-market model) to help or induce farms to invest in the required technology such that these agents can benefit from the functioning of the value chain

\footnotetext{
${ }^{4}$ Related arguments which affect technology indirectly is how a more efficient information exchange along the value chain can form the basis for a competitive advantage of the entire chain, and how more effective value chain governance can enhance the chain's capacity to respond to changing consumer demand or government regulations (Von Hippel, 1988; Williamson, 1985)
} 
with technology adoption at the farm level. One model is that of "interlinked contracting" between farm and processor. The processor provides the farm access to the technology as part of a supply contract with payment conditions. While such interlinked contracts for input provisions have been analyzed in the traditional development literature (e.g. Bardhan 1989; Bell and Srinivasan 1989) ${ }^{5}$, in modern value chains not just basic inputs (such as fertilizer and seed) but much more sophisticated forms of technology transfer occur. Moreover, this is far from the only model. In reality we observe many different forms of value chain innovations with successful technology transfer.

A common element in the different types of value chain innovations is how to enforce technology transfer contracts. Contract enforcement problems not only hamper technological investments by the farmer in a spot market-based value chain, as explained above, but will also hamper the feasibility of technology transfer within the value chain due to potential farmer holdup. Examples of farmer holdup include side-selling of produce after application of the transferred technology, applying the technology to non-contracted products, or selling the transferred technology. Contract enforcement problems have complicated and sometimes prevented technology transfer and adoption.

As we will explain in more detail later in the paper, the contract enforcement problems are influenced by the macro-institutional environment, the type of technologies, and the value in the chain. This implies that there is no one-size-fits-all value chain innovation for technology transfer, but instead one can expect a wide variety in contractual designs to emerge - which is what we observe. In the next section, we therefore review a series of

\footnotetext{
${ }^{5}$ Bell and Srinivasan (1989) define interlinked market transactions as a transaction in which the parties trade in at least two markets on the conditions that the terms of all trade between them are jointly determined. Interlinked market transactions always include an element of credit as they involve exchange of current for future claims. Apart from interlinked credit and output transactions, interlinked transactions also exists in land markets (landlord who provide tenants working capital) and in labor market (employers who give advances to laborers in return for a claim on their labor in peak labor demand periods).
} 
empirical cases of technology transfer through value chain innovations and provide a typology to classify the various empirical cases.

\section{Value Chain Innovations for Technology Transfer: Types and Examples}

In this section we provide a typology of institutional innovations for technology transfer in agricultural value chains and give a series of empirical examples from various countries. All examples have in common that they are set in the context of imperfect financial and technology markets and weak contract enforcing institutions. Several of the examples come from technology transfer in the wake of the liberalization process in Eastern European and the former Soviet Union (FSU). There are two reasons for this. First, the liberalization of markets and the privatization of firms in Eastern Europe and FSU in the 1990s and 2000s created a natural experiment where suddenly existing (state-controlled) value chain systems were abandoned. In the pre-liberalization-era, the technology applied at different stages of the value chain was primarily directed by the state. The shift to a market-led economy led to new competitive pressures and created incentives for firms to improve quality and meet new consumer demand. Improving product quality in a context of failing capital and technology markets and imperfect contract enforcement meant that the private sector was forced to come up with innovative contractual solutions to upgrade the technology in the chain. This unique natural experiment provided a series of interesting case studies with rich implications.

The second reason is that the analysis of Eastern European institutional innovations for technology transfer can provide lessons and implications for developing countries. In many other parts of the world, the liberalization process led to a similar break-down of state controlled value chains (Swinnen et al. 2010). However, the Eastern European experience was different in at least two important aspects. First, per capita income at the time of the liberalization was much higher in Eastern Europe and FSU than in other areas that went 
through a similar liberalization process, such as Sub-Saharan Africa, and South East and East Asia. Second, Eastern Europe received a much greater influx of foreign direct investment (FDI) in the agri-food chains in the years after the economic reforms than Asia and SubSaharan Africa. The higher income of residents in Eastern Europe (as well as the proximity to wealthy Western Europe) increased demand for high quality food after the transition and created an incentive to upgrade the technology at farms and elsewhere in the value chain, while the influx of FDI provided the necessary finance to implement technology transfer.

We increasingly observe other-poorer-parts of the world (Sub-Sahara Africa, Asia and Latin America) entering a phase comparable to Eastern Europe and FSU in the 1990s. Increasing urbanization and consumer purchasing power, increasing FDI in agri-food companies, the rise of supermarkets, and an increase in exports of high value crops give rise to high quality and safety standards also in these areas (Henson and Reardon 2005; Reardon and Timmer 2014). Similarly as in Eastern Europe in the 1990s, complying with these standards requires significant upgrading of production, transport, and storage technology in a context of failing markets and weak governance that induces private-sector-led institutional innovations for value chain technology transfer. Hence, the insights from value chain innovations in Eastern Europe and FSU are highly relevant to understand and to inform policy makers in countries that are currently experiencing similar developments.

We organize our discussion by different types of value chain innovations and Table 1 summarizes key characteristics of the models.

\section{Model 1: Farm - Processor/Retailer Contracting}

Figure 2 illustrates the first model of technology transfer through value chain innovation. This is the case where the company that buys the farm's product (be it a processing, a retailing, or trading company) finances the technology as part of a contract. The contract typically 
specifies an obligation to comply with buyer standards and includes a transfer of technology or of credit for the technology investment linked to a purchasing agreement. Payment for these financial and technological services is generally accounted for at the time of product delivery. The technology that is provided can be rather simple such as specific seeds, fertilizer, or animal feed. However, much more complex forms of technology transfer are also observed, especially in areas where product quality becomes more important and long term investments are required. More advanced forms of contract-farming can include the provision of technological improvements through extension services, technical and managerial assistance, quality control, and specialized transport and storage services. Sometimes contracts also include loans and assistance for medium-term investments but these are more common in contracts that also involve other companies in the value chain (see Models 3 and 4).

Studies on horticultural export chains in Africa document the provision of specific inputs (such as seeds and specific fertilizer) as well as elaborate systems of technical advice and extension services to contracted farmers (Henson et al. 2005). For example, Minten et al. (2009) show that access to technology was a major reason why poor farmers decided to sign up for the contracts with horticultural export companies. Bellemare (2012) shows it is common for exporters and processors in African cotton, rice, barley, and tobacco value chains to provide their suppliers with seeds, pesticides and fertilizer.

There are several studies on Eastern Europe and Central Asia that document complex and elaborate value chain contracting systems in the 1990s and 2000s in various sectors including sugar, dairy, barley, and cotton. Cotton gins in Kazakhstan, for example, not only provided seeds and fertilizer, but also water to the cotton farms, with water irrigation systems being a crucial technological input for farms (Sadler 2006). Dries et al (2009) summarize evidence on dairy contracting systems from various countries showing extensive technology 
transfer. Important components are credit, concentrated animal feed, and technical, veterinary and management advice. Dries and Swinnen (2004; 2010) show, for the case of Poland, that interlinked contracting had a major impact on technology adoption and milk quality, both for small and larger farms.

Van Berkum (2007) documents the case of Danone, the large multinational dairy company, that invested heavily in the Romanian dairy sector. Their main customers were retail chains adhering to European Union standards. Initially, the dairy sector in Romania primarily consisted of small-scale farmers (96\% owned one or two cows) who used very basic production technology and produced low milk quality. In response, Danone put in place arrangements to upgrade the quality of their raw milk supply. This included pre-financing farm technological investments. The company financed suppliers purchasing high-tech inputs (including compound feed and detergents for milking equipment) and offered a range of services to their suppliers including field staff visiting suppliers and advising them on hygienic practices, cleaning, and fodder management. Later on they also introduced programs for longer term technological investments (such as field machinery, cooling equipment, and milking installations) as part of the contracts. By 2010 , as a result of the program, $90 \%$ of the raw milk sourced by Danone complied with European Union standards (Bruszt and Langbein 2014).

Another interesting multi-stage example of technology transfers in value chains is the Eastern European barley-malt-brewing value chains in the 1990s, as documented by Swinnen and Van Herck (2011) and Van Herck et al. (2012). All the major international brewing companies, such as Heineken, Carlsberg, Interbrew (now ABInBev) and SABMiller invested heavily in the privatized Eastern European malting and brewing industry ${ }^{6}$. All of them faced

\footnotetext{
${ }^{6}$ Eastern Europe was seen as an attractive destination for its beer drinking culture, relatively high incomes, and geographic as well as cultural proximity to Western Europe. Due to consumer preferences for local brands, the restrictive import tariffs in some of the countries, and the relatively high transport costs of beer, it was more
} 
the problem of sourcing sufficient high quality barley and malt in order to produce high quality beer. ${ }^{7}$ Enhancing the malt quality required technological upgrading of the entire value chain. For this purpose the brewing companies developed technology transfer programs, involving malting processors, barley farmers, and seed companies (see figure 3). Assistance to farms included seed supply and selection schemes, investment assistance, and advice on postharvest storage and treatment. These programs were successful in both improving quality and productivity. For example, a World Bank (2006) study showed that in Slovakia the yields of barley farmers supplying to Heineken were consistently higher than the average yields of barley producers.

\section{Model 2: Farm - Technology Company Contracting and Leasing}

Technology companies can also be initiators of technology transfer. Like food processing companies, technology companies also benefit if farms purchase the appropriate technology. To assist farms in purchasing the technology (and ensure payments), technology suppliers have engaged in a variety of contracting schemes. Institutional innovations have focused on reducing financial constraints of farms by introducing credit schemes, by assisting farms in selling their products to improve their cash flow and liquidity, and through leasing arrangements.

One common initiative is finance provision by the technology company (i.e. another form of interlinked contracting), sometimes in combination with output purchasing, as illustrated by Figure 4. Foster (1999) describes how a multinational farm equipment manufacturer partnered with local farm equipment distributors to sell combines and tractors to

opportune for these large multinationals to enter the European market through FDI, than by exporting their own international brands into the region (Swinnen and Van Herck 2011).

${ }^{7}$ Initially, the foreign multinationals imported malt from their traditional suppliers in Western Europe. However, afterwards they started to invest in the development of a local supply base. Besides logistical and operational reasons, this was also due to high import tariffs and exchange rate uncertainty. 
farms in Ukraine in the 1990s. Farmers could buy equipment from the distributor using a payment scheme. Initially they had to fulfil 25 percent down-payment (in cash or kind). After three additional payments they received full ownership. To overcome financial constraints of the farms and to ensure payment to the technology company, the equipment dealer received the rights to a certain grain area as part of the payment by the farm. In addition, the equipment dealer was given the rights to harvest, transport, store, and sell the grain. Hence, while the interlinked contracting by the food processing companies in Model 1 made the food company enter the technology market (vertically coordinating in the upstream part of the value chain), here the technology company entered in buying and selling the farms' products (vertically coordinating in the downstream part of the value chain).

For longer term technology investments, such as machinery, technology companies introduced different types of contracting, such as leasing. Leasing is a specific kind of financial contracting, whereby the lessee (the farm) uses the equipment which is still owned by the lessor (the technology company) by paying a periodical fee. In essence it is an in-kind loan, whereby the equipment forms the collateral (since the lessor keeps ownership). Leasing is often used by suppliers of lumpy technological solutions, such as machinery, to "sell" technology to farms that have no access to credit or cannot come up with the necessary collateral for loans.

Other types of value chain innovations for longer term technology investments included more complex forms of contracting where technology companies were part of an institutional design involving multiple partners. We discuss these as Models 3 and 4.

\section{Model 3: Contracting with Multiple Agents -- Triangular Structures}

Processors and technology companies are often reluctant to provide loans to farms for significant technology investments. The reasons are obvious: while "simple" technology 
contracts are risky with contract enforcement problems, the risks are higher with longer term and more expensive technologies. They require substantial amounts of finance and with the increase in the size of the outstanding loans the risk of delayed re-payment or default increases too. In addition, in "simple" technology contracts the time horizon of the technology and the production process coincide (e.g. seeds and fertilizer are linked to one growing season with one harvest). This is no longer the case with longer term investments. Companies have therefore tried to share risk, finance, and monitoring by collaborating with other companies in the value chain in setting up joint programs to provide technology (or investment loans) to farmers.

We refer to institutional designs and collaborations where three agents (including the farm) are involved as triangular structures. The case illustrated by figure 5 is where a processing company and a financial institution set up a joint program. The processing company typically offers a guarantee to the financial institution if it provides a loan to a farm that has a supplier contract with the processor. The guarantee is basically a promise by the processing company that it will assume the debt obligation of the supplier in case of default. The underwriting is for specific loans for technological upgrading related to the contract and restricted for contracting farms. Another example of a triangular structure is where the technology company participates. In this case the processor can provide a payment guarantee directly to the company that sells the technology. The logic is similar. In general, triangular structures require lower financial commitments and less risk for the company initiating the contracting. The financing (loans) is now (at least partially) covered by other companies. Guarantees to financial institutions may also reduce the interest rate for the farmer, as the guarantee lowers the risk for the financial institution.

Guarantee programs within triangular contracting structures were implemented, for example, by sugar processors in Slovakia (Gow et al. 2000), by retailers in Croatia for fruit 
and vegetable supplier investments in greenhouses and irrigation (Dries et al. 2004), by pineapple processors in Ghana (Kolavalli et al. 2015), and by dairy processors in several East European countries (Dries et al. 2009). We will briefly discuss two of these examples in greater detail as they have been well document and because their effects were quite dramatic.

The first case is Gow et al.'s (2000) analysis of value chain innovations in the sugar sector in Slovakia in the 1990s. They document how foreign investors in Slovakian sugar processors introduced several institutional innovations aimed at stimulating technological upgrading by their sugar beet suppliers. As a result of decades of socialist rule and the disruptions caused by the economic transition, productivity and product quality were low throughout the value chain and falling even further. After upgrading the sugar processing plants, these investors set up a triangular contractual arrangement between themselves, the farms that produced sugar beets, and a select group of companies providing technological inputs, such as seeds, chemicals, and fertilizer. The processing company (Juhocukor) negotiated prices with these input companies and guaranteed payment of the purchases. For longer term technological investments (such as for machinery) they set up a similar triangular structure, but instead of including the technology company, they included a financial institution (Polnobanka) through which the sugar beet farms could get loans to finance these investments. Juhocukor provided Polnobanka with a guarantee for the repayment of the loan and subsidized the interest rate.

Gow et al. (2000) emphasize that the guarantee provided by the processor served two purposes. First, it reduced the risk for the technology companies and the bank to supply technology and credit to the farms. Second, it also signaled to farms that the processor was committed to the contracts and planned to honor them-otherwise it would hurt itself. This second element was important in an environment where contract breach and delayed payment 
by sugar processors were widespread, causing financial strains on the farms and making them reluctant to contract and invest. ${ }^{8}$

This package of contractual innovations ${ }^{9}$ was highly successful. Not only did Juhocukor provide sugar beet suppliers with improved access to advanced technologies, but by investing themselves in the triangular structure with their farms they reduced the farms' risk of investment. The result was (a) a substantial increase in beet yields (tons/hectare), (b) a significant improvement of quality (sugar content) on the farms they contracted with, and (c) a growth of the supply base as other farms wanted to contract with them.

Similar triangular structures were introduced in the dairy sector in Eastern Europe in the 1990s and 2000s. Dries and Swinnen (2004; 2010) show that triangular contracting schemes between processors, farms, and banks in the Polish dairy sector led to a significant increase in the use of improved technology, including (higher quality) dairy cows and on-farm cooling equipment. As a result, milk quality and dairy productivity increased strongly throughout the sector.

Interestingly, these value chain innovations not only induced vertical technology transfer but also horizontal technology spillovers. Gow et al (2000) document how contracting systems that were successful in stimulating farm technology upgrading forced other processing companies to offer similar contractual arrangements to attract farms to supply to them. Interestingly, this contractual convergence and subsequent wave of technological upgrading was not confined to a specific sector (in this case sugar). Other sectors that competed for the same resources (land and farms) started to offer similar contracts. Another interesting institutional spillover worth mentioning is that the financial

\footnotetext{
${ }^{8}$ On the impact of holdups and payment delays on farm investments see Cungu et al. (2008).

${ }^{9}$ In addition Juhocukor launched a media campaign and supported its farms by technical advice and extension services. This included agronomical advice, soil testing, extension services on integrated pest management, and management support (see Gow et al. (2000) for details).
} 
institution that was involved later standardized and extended the successful contractual model into a range of financial instruments offered to the entire agricultural sector.

\section{Model 4: Contracting with Multiple Agents -- Special Purpose Vehicles}

An extended form of value chain technology transfer through contracting with multiple agents is the use of so-called "special purpose vehicles" (SPVs). A SPV is a stand-alone company jointly owned by, for example, a processor, a technology provider and a bank (see figure 6), which will contract with the farms. The contract can include provisions on output, technology, and credit. This structure can bring even more partners into the contracting system and again allows to share risk, technology and monitoring among the partners involved.

A big advantage of institutional solutions such as SPVs is that the partners not only share the cost of transferring the technology (and the accompanying monitoring costs), but also share the risk of potential holdup by the farmer. When a processing company by itself implements technology provision programs, the processor carries the entire risk of contract breach, although both the technology provider and the financial institution benefit. Institutions such as SPVs allow sharing of the risk between various agents, and hence will stimulate investments by companies who otherwise may be deterred by this risk. Moreover, embedding the transaction in a larger network offers the opportunity of reducing the risk of farmer holdup by increasing the reputational costs of violating the contract in the form of lost future trading opportunities with the contract partners.

An example described in the literature is the case of the collaboration between the Russian dairy processor Wimm Bill Dann (WBD) and the Swedish dairy equipment seller De Laval (Top Agrar 2004). The goal of the joint project "Milk Rivers" was to upgrade the technology used by Russian farms. They created a jointly owned "project": a SPV that leased 
combine harvesters and milking and cooling equipment. The farmers had to cover about $20 \%$ to $30 \%$ of the costs themselves and received the equipment (provided by De Laval) based on a three to five year leasing basis. The leasing costs were being paid by the farmers by delivering raw milk to WBD. The main condition for suppliers to take part in the program was compliance with WBD quality standards and motivation to improve quality and productivity. Although the project was considered a success, at times the enforcement of the contracts proved difficult, as some of the supported farms started to supply their milk to competitors who offered a higher price. These holdups endangered the feasibility of the scheme (World Bank 2005).

Also in this case horizontal spillover effects have been observed. Serova and Karlova (2010) found that a few years after the WBD-DeLaval project took off, competitors of WBD started copying the scheme to stimulate dairy farm investments. They used a similar construction (also with DeLaval) whereby farms received milking equipment under a leasing contract (as well as technical and veterinary advice and specialized feed and additives) as part of a one- to five-year instalment plan.

\section{Model 5: Vertical Integration}

In some cases companies have gone as far as taking over the farming activities, i.e. by "vertically integrating" the supply of raw materials in their company. Vertical integration is an extreme case of the vertically coordinated programs of Models 1-4. Vertical integration removes the problems of contract enforcement in technology transfer and provides the company full control over technology implementation (including e.g. application of pesticides with strict pesticide residue requirements).

However, it also has drawbacks in terms of inefficiencies of labor management in large integrated farms. Large farms face transaction costs because of principal agent 
problems and monitoring costs in labor contracting, which are typically large in agriculture (Pollak 1985). The importance of these efficiency losses depends on farm specialization and technology, with losses larger for labor intensive activities and where monitoring is more costly (Allen and Lueck 1998). ${ }^{10}$

Moreover, access to land (for new farms created by the downstream company) or takeover of existing farms by companies is non-trivial. It is often difficult to acquire large plots of land due to high farm density in fertile areas or legal constraints (e.g. foreign ownership of land not being allowed). Social pressures (from communities or international civil society) might induce large reputational costs from being associated with "land grabbing". Therefore technology transfer through vertical integration is only observed in specific cases.

One group of technology transfer through vertically integrated systems that have been documented is in export horticulture in Africa. Several studies show how the rise of standards in high value chains and the associated requirement for farmers to invest in modern technology has led towards vertically integrated production systems. For example, Maertens and Swinnen (2009) and Maertens et al. (2011) document how, in the Senegalese horticulture sector the combination of available land (often state or community land) and a tightening of public and private standards (such as HCCP and EurepGAP) induced exporters to move from smallholder contracting to integrated estate production. Similar shifts to vertical integration

\footnotetext{
${ }^{10}$ There is an extensive literature on the optimality of farm sizes and structures (Eswaran and Kotwal, 1985; Feder, 1985; Pollak, 1985). The main arguments relate to relative imperfections in the labor markets versus the capital and product markets and explain empirical findings of an inverse U-function between size and efficiency. Efficiency grows with size for the smallest farms, but beyond a certain size, typically coinciding with larger family farms, there is a declining relation between size and efficiency. Family members have higher incentives to provide effort than hired labor. They share in output risk and can be employed with no or less supervision costs. This is the main advantage of family farming over wage-labor based farming. However, these effects, and hence the "optimum size of the farm" depends on the nature of the farm activity (e.g. livestock, staple crops, horticulture), on the available technology, on relative factor abundance, on market imperfections, and on existing regulations and institutions (Swinnen, 2009). Therefore in environments characterized by major market imperfections, "non-traditional" farm structures may have advantages if they are better fitted for the specific environment. For example, in East Germany in the 1990s, "partnerships" (small groups of farmers that pooled their effort in certain production and marketing tasks) outperformed all other forms of farm organization (Mathijs and Swinnen, 2001).
} 
have been observed in Ghana (Suzuki et al. 2011), Zimbabwe (Henson et al. 2005) and Kenya (Dolan and Humphrey 2000). ${ }^{11}$

In these cases it concerns farms with significant technology investments (e.g. irrigation and greenhouse infrastructure), high opportunity costs of contract breach (with high technology monitoring costs and stringent product standards), and relatively easy access to land (in Senegal the greenhouses are developed on former state farm land). Interestingly, in Madagascar, similar high-value horticultural export chains are based on extensive smallholder contracting. With smallholders occupying all the available suitable land, there is no room for processor-owned large farms and processors are instead sourcing from smallholders. Minten et al. (2009) explain how the processor provides thousands of smallholders key inputs (such as seed and organic fertilizer) and large extension and training programs as part of a contract, but that pesticide application is done by employees of the processor in order to ensure correct technology application on production aspects that are difficult to monitor and crucial for adherence to stringent standards. In this way, part of the production process and technology adoption is also vertically integrated in these smallholder sourcing systems.

A very different form of vertical integration was observed in the large grain producing areas of the former Soviet Union (Kazakhstan, Russia and Ukraine). Technology transfer in this region is focused on basic inputs (seed and fertilizer) in extensive production systems with limited labor input on vast areas of extensively operated grain production systems. Large agro-holdings, with access to finance from international trading, have taken over severely credit constrained farms, sometimes up to hundreds of thousands of hectares, in the aftermaths of the farm privatization schemes of the 1990s (Gataulina et al. 2006). However, this type of vertical integration, while fully in line with the logic of financial constraints as

\footnotetext{
${ }^{11}$ Note that often the shift towards vertical integration has only been partial, as processing companies maintained a mixture of sourcing channels. There are several motivations for this strategy (Suzuki et al. 2011). An important motivation is to maintain multiple and diverse types of suppliers as part of a risk management strategy (Swinnen, 2007). Suzuki et al. (2011) for example, explain why Ghanaian pineapple exporters combine ownestate production with smallholder-sourcing to anticipate unexpected fluctuations in demand.
} 
explained above, appears to be a product of the specific conditions of the transition (including extreme financial constraints and privatization through voucher systems) which are unlikely to occur in other countries (Serova, 2007; Rozelle and Swinnen, 2004).

\section{Discussion and Lessons from the Empirical Cases and Typology}

Several insights can be drawn from the empirical cases and typology.

Imperfect credit markets and access to finance. As is clear from the cases, technology transfer programs can be set up by different agents in the value chain, such as traders, processors, technology companies, retailers or financial institutions. We already pointed at the fundamental role played by credit market imperfections as a motivating element for these value chain innovations. Access to finance by the initiator of the technology transfer program is essential. In all of the empirical cases, the firm that initiated the technology transfer innovation either had significant financial sources or received financial input through outside (sometimes foreign) investment. This is because interlinked contracting, pre-financing and guarantees require large upfront investments or sufficient collateral.

Demand and quality standards. The empirical cases document that a need for quality upgrading of farm production drives value chain technology transfer programs. This was particularly clear after the economic reforms in Eastern Europe, where due to sudden and strong competitive forces and Western European FDI the demand for high quality products was outpacing supply. Similar market developments are now occurring in Sub-Saharan Africa and other developing parts of the world following the growth in high value exports, urbanization, and a rise in domestic purchasing power. However, it appears that a critical level of quality requirements or growth of demand is needed to trigger technology adoption programs. For example, Janssen et al. (2017) find that urbanization and income growth have 
caused a very strong growth in demand for milk and dairy products in India over the past 15 years, but no value chain initiatives to stimulate farm level technology adoption.

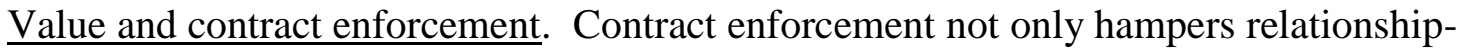
specific technological investments by the farmer in a spot market-based value chain, but will also hamper the feasibility of technology transfer by the buyer due to potential supplier holdup (as explained in section 2.2.). In the absence of public enforcement institutions, hybrid forms of value chain governance can try to cope with such opportunistic behavior through "private enforcement mechanisms", i.e. by ensuring enforcement by a third-party or by including safeguards in the contract to make it "self-enforcing". A contract is self-enforcing when the expected net-present value of additional profit resulting from the contract is greater than the hold-up gains for each party (Klein 1980).

Safeguards can be formal, such as a re-alignment of incentives (e.g. by paying a price premium (Swinnen and Vandeplas 2011)), or informal, such as reputation or goodwill trust (Dyer and Singh 1998). Safeguards and third-party enforcement are, however, costly solutions as they involve monitoring of contract compliance and other (coordination) costs. ${ }^{12}$ These solutions are therefore more likely to be feasible when sufficient value is created by the transfer, part of which can be used to finance the enforcement mechanisms (Swinnen and Vandeplas 2011). This might not be possible if too little value is created by the technology adoption. Technology transfer is therefore more likely to occur in high value market segments.

Nature of the technology. Another important factor affecting the risk of holdup, and therefore the feasibility of a transfer, is the type of technology that is being transferred. It is well known that the specificity of the technology with respect to the relationship between the farmer and the firm providing the technology plays an important role in contracting and the

\footnotetext{
${ }^{12}$ Moreover, contracts will to some extent remain incomplete due to drafting costs and asymmetric information (Grossman and Hart 1986). Therefore, as opportunistic behavior cannot be ruled out and ex-post bargaining costs have to be anticipated, it is unavoidable that some "residual holdup risk" will remain.
} 
institutions that can enforce the contract (Klein et al. 1978; Williamson 1985). If the technology is $100 \%$ specific to the transaction (e.g. technology needed to comply with company specific private standards, such as a traceability system), it has no value outside the contract; if it (or its effects) are also valued by others (e.g. in the case of fertilizer) the technology is non-specific. Obviously, the benefits of diverting technology that is nonspecific will more be beneficial than diverting technologies that are very specific to the relationship, which makes transferring non-specific technology more risky.

Another dimensions of technology is the time dimension. As the empirical cases document (and Table 1 summarizes) there is a difference in the value chain innovations between short and longer term technologies. Technology embedded in short-run inputs (e.g. fertilizer, seeds, feed additives, detergent) are typically used up in the production process. Other technologies come in the form of assets and can have a long-term influence on the production process (e.g. transfer of knowledge or machinery). Short-run technologies are typically closer linked to the contracting period. In contrast, long term technology may have effects beyond the contract period. These different time horizons influence the contract enforcement feasibility. This is because supplier holdup rewards for diverting technology are larger for technology with long-term benefits, while reputational costs are expected to be smaller-making contract breach more likely and therefore technology transfers less likely under standard interlinked contracts. Hence, in order to make long term technology transfers work more sophisticated institutional mechanisms might be required which increase the costs of contract breach for the farm and which reduce the risk of contract breach for the contracting company. Alternatively, it may require a more stable macro-economic and institutional environment which contributes to reducing the risk of contract breach.

Form of VC Model (1\&2 versus 3\&4). A multi-agent institutional organization has probably a higher up-front investment in the form of contracting and negotiation costs than a 
simpler 2-agent interlinked contracting scheme because there are more parties involved and there are more contracts to be designed. ${ }^{13}$ Moreover, partnering with additional agents introduces the possibility of opportunistic behavior by any of those agents. ${ }^{14}$ This might either result in a higher residual holdup risk or requires more costly contractual safeguards (Table 2). The advantages of involving multiple value chain agents in technology transfer are (1) that once the governance structure is set-up, the costs of actually transferring the technology (e.g. training of farmers, transporting farm-inputs, installing equipment) and the costs for monitoring the farmer and enforcing compliance with the contract can be shared among multiple agents; (2) that the financial capability of the initiator of the scheme can be lower; and (3) is that the partners can share the residual risk of holdup by the farmer.

What type of VC Model will be preferred is therefore expected to depend on the level of each of these cost categories. Multi-agent solutions become comparatively more attractive if higher up-front set-up costs and the risk of partner hold-up are sufficiently offset by lower technology transfer costs, lower monitoring and enforcement costs, and lower residual risk of farmer holdup. This is likely to be the case with longer term and more capital-intensive investments (such as medium and long term investments as described in Models 3 and 4 in Section 3).

Form of VC Model (1-4 versus 5 (Vertical integration)). Williamson (1991) argues that "hybrid" forms of value chain organization (e.g. interlinked contracting schemes, triangular structures, or SPVs) compared to vertically integrated companies are better able to respond to price changes in the economy as they preserve autonomous ownership. However, as the dependency among value chain actors becomes larger and coordination becomes more

\footnotetext{
${ }^{13}$ Dyer (1997) refers to this upfront investment as "governance set-up costs" which are transaction costs that are incurred before the actual transaction. These include the costs of screening partners, negotiating terms, building trust, and designing the contract. We follow Dyer by arguing that these initial set-up costs subsequently affect the transaction costs incurred after the contract is signed.

${ }^{14}$ For example, in both the triangular structure and the SPV it is the technology company and financial institution that have to make the first (relationship-specific) investment. The processor is therefore in the position to hold up both these partners as it can re-negotiate contract terms once the investment is made.
} 
important, vertical integration becomes a comparatively more efficient form of organization. ${ }^{15}$ As discussed, this is in line with our empirical cases that show that as a result of more stringent private and public standards and the need to transfer technology, processors became more dependent on farmers and the quality of their produce. In some cases this led to (partial) vertical integration.

However, our empirical review suggests that there are also other factors, beyond a minimization of transaction costs, why vertical integration is (not) chosen. Land, for example, is often not easily accessible due to legal or social constraints. Moreover, small autonomous farms might be preferred over large integrated farms simply because they are more efficient for certain (labor-intensive) products (see Section 3.5). In those cases, hybrid forms of value chain governance might be the more profitable solution to realize the technology transfer.

Farm Organizations and Value Chains. Reports by development organizations, such as FAO, the World Bank, and NGOs, invariably point at the important role that farm organizations can play in value chains. Conceptually, several reasons have been put forward why farm organizations (such as cooperatives) could enhance technology adoption through value chains. First, a collective marketing agreement with a processor or trader might secure a market outlet for their products, reducing the risk of relationship specific investments. Second, through collective bargaining cooperatives might be able to obtain higher output prices, increasing the return on investment and obtain discounts on equipment, inputs and services. Lumpy investments (e.g. harvesting machinery) might be collectively purchased and hired out to members for a fee. Third, cooperatives might enhance access to credit.

\footnotetext{
${ }^{15}$ The transaction costs of a hybrid governance form (including the safeguard costs, residual holdup costs, and the cost of the transfer itself) are amplified when suppliers are small and many, monitoring contract-compliance is difficult, and when the capability of the farmer is low, standards and technology are complex, and the required technology is difficult to codify in a set of well-defined practices (Gereffi et al. 2005). Vertical integration avoids these type of transaction costs (and holdup altogether) and thus becomes comparatively more attractive as these costs increase.
} 
Collectively taking a loan can reduce transaction costs and collectively guaranteeing repayment reduces the risk of default following idiosyncratic shocks. Fourth, cooperatives may reduce transaction costs for retailers and food processing companies in sourcing from (small) farmers by pooling supplies and controlling quality. Fifth, cooperatives may also play a role in joint quality control systems. As prices are typically related to quality in modern supply chains, transparency of quality control is a crucial factor to prevent holdups in contracting and, therefore, to make value chains function effectively. Involvement of farm organizations in quality control may help in this. In summary, there are many reasons why farm organizations could play an important role in value chains and innovations.

However, in reality participation by farmers' organizations in these value chain innovations appears rather limited. A few cases that have been documented include a reference by Gow and Swinnen (2001) to how a sheep farmer organization in Hungary in the 1990s participated as a partner in a SPV structure and increased farmers' bargaining power in the contract design. ${ }^{16}$ Van Berkum (2007) and Bruszt and Langbein (2014) describe how a dairy farmers association (ISPA) in Romania became a shareholder in a milk processing company (ProMilch) in the late 1990s. ${ }^{17}$ Hence, the discrepancy between the conceptual benefits and the absence of empirical success cases is intriguing and certainly an interesting area for future research.

Competition. The cases we presented have not dealt explicitly with competition issues. Although it is well known that competition affects contract enforcement, the impact is not as straightforward as may seem. Swinnen and Vandeplas (2010) develop a formal model

\footnotetext{
${ }^{16}$ A case from a developed country is presented by Jardine et al. (2014) who describe how an Alaskan fishery cooperative took ownership in the processing stage of the value chain and how this addressed market failures and improved product quality.

${ }^{17}$ ISPA supported their members in upgrading their technology in several ways: (a) by investing in milk collection centers; (b) by supplying high-quality inputs (feed, medication), which were financed by deducting milk payments; (c) by offering on-farm technical assistance (on a range of topics); and by providing loans to their members (in collaboration with a financial institution (Rabobank)) to invest in equipment, animals, or (re)construction of stables. Farmers did not have to provide any collateral, but needed to have a durable relation with ISPA, and continue milk delivery to the cooperative.
} 
and show that the impact is complex because of several mechanisms that are influenced by competition. More competition will induce more incentives for companies to contract with farmers and will improve contract conditions for farmers ex ante. However, more competition may also lead to more options for contract breach (side-selling) ex post, and thus reduce the expected likelihood of contract enforcement, and, as companies anticipate this, a lower likelihood of value chain innovations being introduced. Inversely, a more concentrated processing or technology sector may lead to worse contract conditions for the farms because of reduced bargaining power and to a greater chance of ex post holdup by the company but at the same time may make contract enforcement more likely. Recently, Mérel and Sexton (2017) argued that there may be an optimal level of competition at which contracts can be beneficial for both parties and where hold-up chances are minimized.

Institutional environment and macro-economic stability. The institutional and macroeconomic environment obviously play a role since they affect the severity of the capital and technology market imperfections directly as well as indirectly through (expected) problems with contracting and contract enforcement. For example, more sophisticated contracting systems (such as triangular structures) and contracts with programs for longer term technology investments (such as investment loans) did not occur in all transition countries. Studies by Sadler et al. (2006) on the cotton sector in Kazakhstan and by White and Gorton (2006) who interviewed a wide variety of agri-food companies in five FSU countries (Russia, Ukraine, Moldova, Armenia and Georgia) found that many agri-food companies in these countries only provided basic inputs and technology (such as seeds and fertilizer) under contracts as discussed above but did not provide long term investment loans. Neither did they engage in triangular structures. These observations suggest that certain conditions (for example relating to the economic and institutional environment) may need to be fulfilled before more complex value chain innovations may emerge. 
Dealing with changing circumstances. The technology transfer programs have been set up in environments characterized by strong market imperfections and costly contract enforcement. Successful programs create the right conditions for successful and self-enforcing contracting, and are based on extensive knowledge of the sector and of local conditions. Moreover, these programs need to be flexible enough to adjust the contractual terms to changing circumstances - an often occurring situation in developing and emerging economies. Too large disruptions make contracting infeasible.

Impacts. The effects of these programs can be very substantial as they can move the entire value chain towards a higher equilibrium, with impacts for all agents. Spillovers are not restricted to vertical interactions, but can also be horizontal. Competing companies of firms that initiate a technology transfer program may introduce similar contractual arrangements, either to stay in business (as farms will otherwise shift to supplying other companies) or because it is profitable for them to do so once they observe the success of the innovations elsewhere - or both. Such type of contractual convergence may go beyond sectors in which the transfer program was initiated. Other sectors that compete for the same resources (e.g. land) might offer similar contracts as well - or financial institutions may standardize the approach for other farms.

\section{Conclusions and Implications}

The adoption of modern technologies is crucial for improving the productivity and welfare of poor farmers in developing countries but technology adoption has been constrained. Many factors have been identified, but the role of value chains has not received much attention so far. In this paper we have explained why value chains and institutional innovations may play an important role in agricultural technology adoption. With imperfect technology markets, various forms of value chain innovations have been introduced by up- 
and downstream companies to overcome constraints and enhance farmer access to and adoption of new technologies. We have systematically documented value chain innovations, including smallholder contracting with interlinked technology transfer, triangular guarantee structures with technology suppliers or financial institutions, special purpose vehicles and vertical integration We discussed how the type of $\mathrm{VC}$ models and their success is related to various factors, including the nature of the technology requirements in product and process standards, the value created by the technology adoption, the macro-institutional and economic conditions, the nature of the technology (timing and specificity), the need for finance and risk-sharing among value chain agents, and competition in the value chain.

Important questions relate to the policy implications of our analysis. The most straightforward implication relates to recognizing the importance of value chains as an engine for technology adoption, and to the need for allowing this engine to work its best. A key policy to stimulate technology transfer and adoption in the agricultural sector of developing and emerging countries is therefore to improve the enabling environment for companies to operate in. Enabling environments encompasses various macro-economic and macroinstitutional elements.

Macro-economic stability is a key condition for financial markets to function properly. Instability may increase the risk of holdup, as unexpected changes in economic conditions might make it more attractive to default on the contract. Hence, macro-economic stability is not only necessary for the functioning of more traditional finance systems, but also for technology transfer as it reduces the risk of investments.

One of the key findings of our review is that there exists significant variation in private sector technology transfer schemes across countries and sectors. Hence, one should be careful with interventions that may hamper the flexibility of companies to address different circumstances. 
Private sector technology transfer might only be feasible for high-value market segments and for certain types of technology. In particular, there is less incentive for transferring long-term oriented technology that is not to some extent relationship-specific, due to a higher risk of supplier hold up (e.g. training on how to increase yields). One could therefore consider public interventions which focus on those firms or farms being excluded from private sector programs, those low-value market segments for which technology transfer is unlikely, and those technologies that are not provided by the private sector. ${ }^{18}$ These public programs could learn from the institutional design of the private sector in bringing different partners to the table.

Another option is to leverage the private sector's resources and use value chains for transferring technology to farms. As we showed, access to finance is essential for technology transfer. Therefore, one way to facilitate technology transfer is by offering government finance for private-sector-led technology transfer programs that could otherwise not be financed. This can be achieved through different modalities, such as public-private partnerships involving grants or (concessional) loans.

Alternatively, governments (and NGOs) could directly assist suppliers in upgrading technology (e.g. through training, improving access to essential inputs, and facilitating certification) in anticipation of increasing market demand for high quality produce, or, more actively, in close collaboration with the private sector. Unlike traditional technology adoption programs, these initiatives complement a government initiated productivity push, with a private "market pull". Waddington et al. (2014) review the effectiveness of public agricultural extension services and find effects are particularly large when they are implemented alongside complementary upstream or downstream interventions (access to seeds and other inputs, assistance in marketing produce).

\footnotetext{
${ }^{18}$ Note that the same market failures that exist in high-value market segments can exist in low-value segments, such as high transaction costs in credit markets and information asymmetries.
} 
In fact these type of value chain development projects have become increasingly popular among donors active in rural developing areas. A recent example is a joint World Bank - World Food Programme project to set up a staple food sourcing program in East Africa in which it collaborates with private sector input suppliers (seed, fertilizer and pesticides) in an SPV-like institutional organization with smallholder farmers to source staple foods (cereals) from them. Another example is a project by the NGO Solidaridad in the horticulture, aquaculture and dairy sector of South-West Bangladesh (Kuijpers 2017). They have an intensive 5-year long program in which they are continuously coordinating their farmer assistance to buyer needs and requirements. This farmer assistance includes group formation, training, certification, and creating access to high quality farm inputs and services.

The effectiveness of these programs is, however, only rarely evaluated "rigorously", and most of those studies have appeared in the "gray literature". An exception is Shayonan et al. (2014) who document how a public-private-partnership for technology transfer in Armenia led to a sustainable upgrading of supplier technology. They show how an international aid program (the USDA Marketing Assistance Program) that facilitated linkages between dairy processors and dairy farmers stimulated technology upgrading and investments by these farmers in cows, husbandry facilities and milking equipment, even after the program ended.

However, as all public interventions, also this type of selective government involvement in markets carries a number of risks. For example, the government financing might not be "additional" to private sector initiatives (DCED 2014) or the project may not be sustainable beyond the public funding.

As still little is known about what type of intervention works best in what type of context, further research on this topic, as well as, rigorous monitoring and evaluation of initiated programs is needed. As the impact of the value chain innovations that we have 
documented here are potentially very significant, these are research areas with a potentially high pay-off.

\section{References}

Allen, Douglas W., and Dean Lueck. 1998. "The Nature of the Farm." The Journal of Law and Economics 41 (2): 343-386.

Andersson, Camilla IM, Christine GK Chege, Elizaphan JO Rao, and Matin Qaim. 2015. "Following up on Smallholder Farmers and Supermarkets in Kenya." American Journal of Agricultural Economics 97 (4): 1247-1266. doi:10.1093/ajae/aav006

Banerjee, Abhijit V., and Esther Duflo. 2014. "Do Firms Want to Borrow More? Testing Credit Constraints Using a Directed Lending Program." The Review of Economic Studies 81 (2): 572-607. doi:10.1093/restud/rdt046.

Bardhan, P. 1989. The Economic Theory of Agrarian Institutions. Clarendon Press.

Bardhan, Pranab, and Christopher Udry. 1999. Development Microeconomics. Oxford University Press.

Barney, Jay. 1991. "Firm Resources and Sustained Competitive Advantage." Journal of Management 17 (1): 99-120.

Barrett, Christopher B., Maren E. Bachke, Marc F. Bellemare, Hope C. Michelson, Sudha Narayanan, and Thomas F. Walker. 2012. "Smallholder Participation in Contract Farming: Comparative Evidence from Five Countries." World Development 40 (4): 715-30. doi:10.1016/j.worlddev.2011.09.006.

Bell, Clive, and T. N. Srinivasan. 1989. "Interlinked Transactions in Rural Markets: An Empirical Study of Andhra Pradesh, Bihar and Punjab." Oxford Bulletin of Economics and Statistics 51 (1): 73-83.

Bellemare, Marc F. 2012. "As You Sow, so Shall You Reap: The Welfare Impacts of Contract Farming." World Development 40 (7): 1418-1434.

Bold, Tessa, Kayuki C. Kaizzi, Jakob Svensson, and David Yanagizawa-Drott. 2015. "Low Quality, Low Returns, Low Adoption: Evidence from the Market for Fertilizer and Hybrid Seed in Uganda." HKS Faculty Research Working Paper Series, June. http://epod.cid.harvard.edu/files/epod/files/rwp15_033_yanagizawa.pdf.

Bruszt, Laszlo, and Julia Langbein. 2014. "Strategies of Regulatory Integration via Development: The Integration of the Polish and Romanian Dairy Industries into the EU Single Market." In Leveling the Playing Field: Transnational Regulatory Integration and Development. Oxford: Oxford University Press.

Cungu, Azeta, Hamish Gow, Johan F. M. Swinnen, and Liesbet Vranken. 2008. "Investment with Weak Contract Enforcement: Evidence from Hungary during Transition." European Review of Agricultural Economics 35 (1): 75-91. doi:10.1093/erae/jbn001.

DCED. 2014. "Demonstrating Additionality in Private Sector Development Initiatives; A Practical Exploration of Good Practice for Challenge Funds and Other Cost-Sharing Mechanisms."

Dolan, Catherine, and John Humphrey. 2000. "Governance and Trade in Fresh Vegetables: The Impact of UK Supermarkets on the African Horticulture Industry." Journal of Development Studies 37 (2): 147-176.

Dries, Liesbeth, Etleva Germenji, Nivelin Noev, and Johan F. M. Swinnen. 2009. "Farmers, Vertical Coordination, and the Restructuring of Dairy Supply Chains in Central and 
Eastern Europe.” World Development 37 (11): 1742-58.

doi:10.1016/j.worlddev.2008.08.029.

Dries, Liesbeth, and Johan F. M. Swinnen. 2004. "Foreign Direct Investment, Vertical Integration, and Local Suppliers: Evidence from the Polish Dairy Sector." World Development 32 (9): 1525-44. doi:10.1016/j.worlddev.2004.05.004.

. 2010. "The Impact of Interfirm Relationships on Investment: Evidence from the Polish Dairy Sector." Food Policy 35 (2): 121-29. doi:10.1016/j.foodpol.2009.11.005.

Dyer, Jeffrey H. 1997. "Effective Interfirm Collaboration: How Firms Minimize Transaction Costs and Maximize Transaction Value." Strategic Management Journal, 535-556.

Dyer, Jeffrey H., and Harbir Singh. 1998. "The Relational View: Cooperative Strategy and Sources of Interorganizational Competitive Advantage." Academy of Management Review 23 (4): 660-679.

Economides, Nicholas. 1996. "The Economics of Networks." International Journal of Industrial Organization 14 (6): 673-699.

Eswaran, Mukesh, and Ashok Kotwal. 1985. "A Theory of Contractual Structure in Agriculture." The American Economic Review 75 (3): 352-67.

Evenson, Robert E., and Douglas Gollin. 2003. "Assessing the Impact of the Green Revolution, 1960 to 2000." Science 300 (5620): 758-62. doi:10.1126/science.1078710.

Feder, Gershon. 1985. "The Relation between Farm Size and Farm Productivity: The Role of Family Labor, Supervision and Credit Constraints." Journal of Development Economics 18 (2-3): 297-313.

Feder, Gershon, Richard E. Just, and David Zilberman. 1985. "Adoption of Agricultural Innovations in Developing Countries: A Survey." Economic Development and Cultural Change 33 (2): 255-298.

Foster, Andrew D., and Mark R. Rosenzweig. 2010. "Microeconomics of Technology Adoption." Annual Review of Economics 2 (September). doi:10.1146/annurev.economics.102308.124433.

Foster, Christian. 1999. "The Impact of FDI in the Upstream and Downstream Sectors on Investment in Agriculture in the NIS." Agricultural Finance and Credit Infrastructure in Transition Economies, 198-211.

Gataulina, Ekaterina A., Vasilii Y. Uzun, Alexander V. Petrikov, and Renata G. Yanbykh. 2006. "Vertical Integration in an Agroindustrial Complex: Agrofirms and Agroholdings in Russia." In The Dynamics of Vertical Coordination in Agrifood Chains in Eastern Europe and Central Asia: Case Studies, edited by Johan Swinnen, 45-71. Washington D.C.: The World Bank.

Gereffi, Gary, John Humphrey, and Timothy Sturgeon. 2005. "The Governance of Global Value Chains." Review of International Political Economy 12 (1): 78-104.

Gow, Hamish R., Deborah H. Streeter, and Johan F.M. Swinnen. 2000. "How Private Contract Enforcement Mechanisms Can Succeed Where Public Institutions." Agricultural Economics 23 (3): 253-65. doi:10.1111/j.1574-0862.2000.tb00277.x.

Gow, Hamish R., and Johan Swinnen. 1998. "Up-and Downstream Restructuring, Foreign Direct Investment, and Hold-up Problems in Agricultural Transition." European Review of Agricultural Economics 25 (3): 331-350.

Gow, Hamish R., and Johan F. M. Swinnen. 2001. "Private Enforcement Capital and Contract Enforcement in Transition Economies." American Journal of Agricultural Economics 83 (3): 686-90.

Grossman, Sanford J., and Oliver D. Hart. 1986. "The Costs and Benefits of Ownership: A Theory of Vertical and Lateral Integration." Journal of Political Economy 94 (4): 691719. 
Hart, Oliver, Jean Tirole, Dennis W. Carlton, and Oliver E. Williamson. 1990. "Vertical Integration and Market Foreclosure." Brookings Papers on Economic Activity. Microeconomics 1990: 205-286.

Havranek, Tomas, and Zuzana Irsova. 2011. "Estimating Vertical Spillovers from FDI: Why Results Vary and What the True Effect Is." Journal of International Economics 85 (2): 234-244.

Henson, Spencer, Oliver Masakure, and David Boselie. 2005. "Private Food Safety and Quality Standards for Fresh Produce Exporters: The Case of Hortico Agrisystems, Zimbabwe.” Food Policy 30 (4): 371-84. doi:10.1016/j.foodpol.2005.06.002.

Henson, Spencer, and Thomas Reardon. 2005. "Private Agri-Food Standards: Implications for Food Policy and the Agri-Food System." Food Policy 30 (3): 241-253.

Hippel, Eric von. 1988. The Sources of Innovation. Oxford University Press.

Janssen, Emma, Mara Squicciarini, and Johan Swinnen. 2017. "Technology Adoption and Value Chains in Developing Countries: Evidence from Dairy in India." Working paper.

Jardine, Sunny L., C.-Y. Cynthia Lin, and James N. Sanchirico. 2014. "Measuring Benefits from a Marketing Cooperative in the Copper River Fishery." American Journal of Agricultural Economics 96 (4): 1084-1101. doi:10.1093/ajae/aau050.

Keller, Wolfgang. 2004. "International Technology Diffusion." Journal of Economic Literature 42 (3): 752-782.

Klein, Benjamin, Robert G. Crawford, and Armen A. Alchian. 1978. "Vertical Integration, Appropriable Rents, and the Competitive Contracting Process." The Journal of Law \& Economics 21 (2): 297-326.

Klein, Benjamin. 1980. “Transaction Cost Determinants Of 'unfair' contractual arrangements." The American Economic Review, 356-362.

Kolavalli, Shashidhara, Akwasi Mensah-Bonsu, and Saima Zaman. 2015. "Agricultural Value Chain Development in Practice: Private Sector-Led Smallholder Development.” SSRN Scholarly Paper. Rochester, NY: Social Science Research Network. https://papers.ssrn.com/abstract=2685303.

Kuijpers, Rob. "Integrated Value Chain Development and Food Security: Evidence from Bangladesh." Paper presented at the GlobalFood Symposium, Göttingen, April 2017.

Kuijpers, Rob, and Johan Swinnen. 2016. "Value Chains and Technology Transfer to Agriculture in Developing and Emerging Economies." American Journal of Agricultural Economics 98 (5): 1403-18. doi:10.1093/ajae/aaw069.

Lambrecht, Isabel, Bernard Vanlauwe, Roel Merckx, and Miet Maertens. 2014. "Understanding the Process of Agricultural Technology Adoption: Mineral Fertilizer in Eastern DR Congo." World Development 59 (July): 132-46. doi:10.1016/j.worlddev.2014.01.024.

Maertens, Miet, Liesbeth Colen, and Johan FM Swinnen. 2011. "Globalisation and Poverty in Senegal: A Worst Case Scenario?” European Review of Agricultural Economics 38 (1): 31-54. doi: 10.1093/erae/jbq053

Maertens, Miet, and Johan Swinnen. 2009. "Trade, Standards, and Poverty: Evidence from Senegal.” World Development 37 (1): 161-178.

Martins, Pedro S., and Yong Yang. 2009. "The Impact of Exporting on Firm Productivity: A Meta-Analysis of the Learning-by-Exporting Hypothesis." Review of World Economics 145 (3): 431-445.

Mathijs, Erik and Johan Swinnen. 2001. "Production Organization and Efficiency during Transition: An Empirical Analysis of East German Agriculture." The Review of Economics and Statistics 83(1):100-107. 
Mérel, Pierre, and Richard J. Sexton. 2017. "Buyer Power with Atomistic Upstream Entry: Can Downstream Consolidation Increase Production and Welfare?" International Journal of Industrial Organization 50 (January): 259-93. doi:10.1016/j.ijindorg.2016.11.002.

Michelson, Hope C. 2013. "Small Farmers, NGOs, and a Walmart World: Welfare Effects of Supermarkets Operating in Nicaragua." American Journal of Agricultural Economics 95 (3): 628-649.

Milgrom, Paul, and John Roberts. 1990. "The Economics of Modern Manufacturing: Technology, Strategy, and Organization.” The American Economic Review, 511-528.

Minten, Bart, Lalaina Randrianarison, and Johan F.M. Swinnen. 2009. "Global Retail Chains and Poor Farmers: Evidence from Madagascar." World Development 37 (11): 172841. doi:10.1016/j.worlddev.2008.08.024.

Pollak, Robert A. 1985. "A Transaction Cost Approach to Families and Households." Journal of Economic Literature 23 (2): 581-608.

Reardon, Thomas, Christopher B. Barrett, Julio A. Berdegué, and Johan F.M. Swinnen. 2009. "Agrifood Industry Transformation and Small Farmers in Developing Countries." World Development 37 (11): 1717-27. doi:10.1016/j.worlddev.2008.08.023.

Reardon, Thomas, and C. Peter Timmer. 2007. "Transformation of Markets for Agricultural Output in Developing Countries since 1950: How Has Thinking Changed?" Handbook of Agricultural Economics 3: 2807-2855. . 2014. "Five Inter-Linked Transformations in the Asian Agrifood Economy: Food Security Implications.” Global Food Security 3 (2): 108-17. doi:10.1016/j.gfs.2014.02.001.

Reardon, Thomas, C. Peter Timmer, Christopher B. Barrett, and Julio Berdegué. 2003. "The Rise of Supermarkets in Africa, Asia, and Latin America." American Journal of Agricultural Economics 85 (5): 1140-1146.

Rozelle, Scott, and Johan FM Swinnen. 2004. "Success and Failure of Reform: Insights from the Transition of Agriculture." Journal of Economic Literature 42 (2): 404-456.

Sadler, Marc. 2006. "Vertical Coordination in the Cotton Supply Chains in Central Asia." In The Dynamics of Vertical Coordination in Agrifood Chains in Eastern Europe and Central Asia: Case Studies, edited by Johan Swinnen, 73-114. Washington D.C.: The World Bank.

Saenger, Christoph, Maximo Torero, and Matin Qaim. 2014. "Impact of Third-Party Contract Enforcement in Agricultural Markets-A Field Experiment in Vietnam." American Journal of Agricultural Economics, 44 (3): 297-308. doi:10.1093/ajae/aau021.

Serova, Eugenia.07. "Agro-Holdings: Vertical Integration in Agri-Food Supply Chains in Russia." In Global Supply Chains, Standards and the Poor: How the Globalization of Food Systems and Standards Affects Rural Development and Poverty, edited by Johan Swinnen, 188-206. Wallingford: Cabi International.

Serova, Eugenia, and Natalia Karlova. 2010. "The Russian Federation: Review of the Dairy Sector." FAO Investment Centre Studies and Reports. FAO. http://www.fao.org/documents/card/en/c/43492ba8-7012-411e-a77c-d5f85d0a8ed0.

Shanoyan, Aleksan, R. Brent Ross, Hamish R. Gow, and H. Christopher Peterson. 2014. "Long-Term Sustainability of Third-Party Facilitated Market Linkages: Evidence from the USDA Marketing Assistance Program in the Armenian Dairy Industry." Food Policy 46 (June): 157-64. doi:10.1016/j.foodpol.2014.03.013.

Sheahan, Megan, and Christopher B. Barrett. 2014. "Understanding the Agricultural Input Landscape in Sub-Saharan Africa: Recent Plot, Household, and Community-Level Evidence.” Policy Research Working Paper. The World Bank Group, August. 
https://openknowledge.worldbank.org/bitstream/handle/10986/20346/WPS7014.pdf?s equence $=1$

Subervie, Julie, and Isabelle Vagneron. 2013. "A Drop of Water in the Indian Ocean? The Impact of GlobalGap Certification on Lychee Farmers in Madagascar." World Development 50: 57-73.

Suri, Tavneet. 2011. "Selection and Comparative Advantage in Technology Adoption." Econometrica 79 (1): 159-209. doi:10.3982/ECTA7749.

Suzuki, Aya, Lovell S. Jarvis, and Richard J. Sexton. 2011. "Partial Vertical Integration, Risk Shifting, and Product Rejection in the High-Value Export Supply Chain: The Ghana Pineapple Sector." World Development 39 (9): 1611-1623.

Swinnen, Johan, and Kristine Van Herck. 2011. "How the East Was Won: The Foreign TakeOver of the Eastern Beer Market." In The Economics of Beer. Oxford University Press.

Swinnen, Johan. 2007. Global Supply Chains, Standards and the Poor: How the Globalization of Food Systems and Standards Affects Rural Development and Poverty. Wallingford: Cabi International.

Swinnen, Johan. 2009. "Reforms, Globalization, and Endogenous Agricultural Structures." Agricultural Economics 40(6): 719-732.

Swinnen, Johan F. M., Anneleen Vandeplas, and Miet Maertens. 2010. "Liberalization, Endogenous Institutions, and Growth: A Comparative Analysis of Agricultural Reforms in Africa, Asia, and Europe." The World Bank Economic Review 24 (3): 412 45. doi:10.1093/wber/lhq017.

Swinnen, Johan, and Miet Maertens. 2007. "Globalization, Privatization, and Vertical Coordination in Food Value Chains in Developing and Transition Countries." Agricultural Economics 37 (s1): 89-102.

Swinnen, Johan, Thijs Vandemoortele, Koen Deconinck, and Anneleen Vandeplas. 2015. Quality Standards, Value Chains, and International Development: Economic and Political Theory. Camebridge: Cambridge University Press.

Top Agrar. 2004. "Russische Milchviehhalter Bekommen Neu Melktechnik." Top Agrar, May 6.

Van Berkum, S. 2007. "Vertical Coordination in the Dairy Sector: A Comparative Analysis of Romania and Slovakia." In Global Supply Chains, Standards and the Poor: How the Globalization of Food Systems and Standards Affects Rural Development and Poverty, edited by Johan Swinnen, 241-256. Wallingford: Cabi International.

Van Herck, Kristine, Johan FM Swinnen, Koen Deconinck, and others. 2012. "How the East Was Won: Supply Chain Restructuring in the Eastern European Beer Market." Journal of International Agricultural Trade and Development 61 (4).

Waddington, Hugh, Birte Snilstveit, Jorge Garcia Hombrados, Martina Vojtkova, Jock Anderson, and Howard White. 2014. "Farmer Field Schools for Improving Farming Practices and Farmer Outcomes in Low-and Middle-Income Countries: A Systematic Review." Campbell Systematic Reviews 10 (6).

White, John, and Matthew Gorton. 2006. "A Comparative Study of Agrifood Chains in Moldova, Armenia, Georgia, Russia, and Ukraine." In The Dynamics of Vertical Coordination in Agrifood Chains in Eastern Europe and Central Asia: Case Studies, edited by Johan Swinnen, 5-44. Washington D.C.: The World Bank.

Williamson, Oliver E. 1985. The Economic Intstitutions of Capitalism. Simon and Schuster. 1991. "Comparative Economic Organization: The Analysis of Discrete Structural Alternatives.” Administrative Science Quarterly, 269-296. 
World Bank. 2005. "The Dynamics of Vertical Coordination in Agrifood Chains in Eastern Europe and Central Asia : Implications for Policy and World Bank Operations”. Washington D.C.: The World Bank.

. 2006. "Market Linkages in the Slovak Agri-Food Sector", Working Paper No. 43. The World Bank. 
Figure 1: Value Chain and Technology Transfer with Perfect Markets

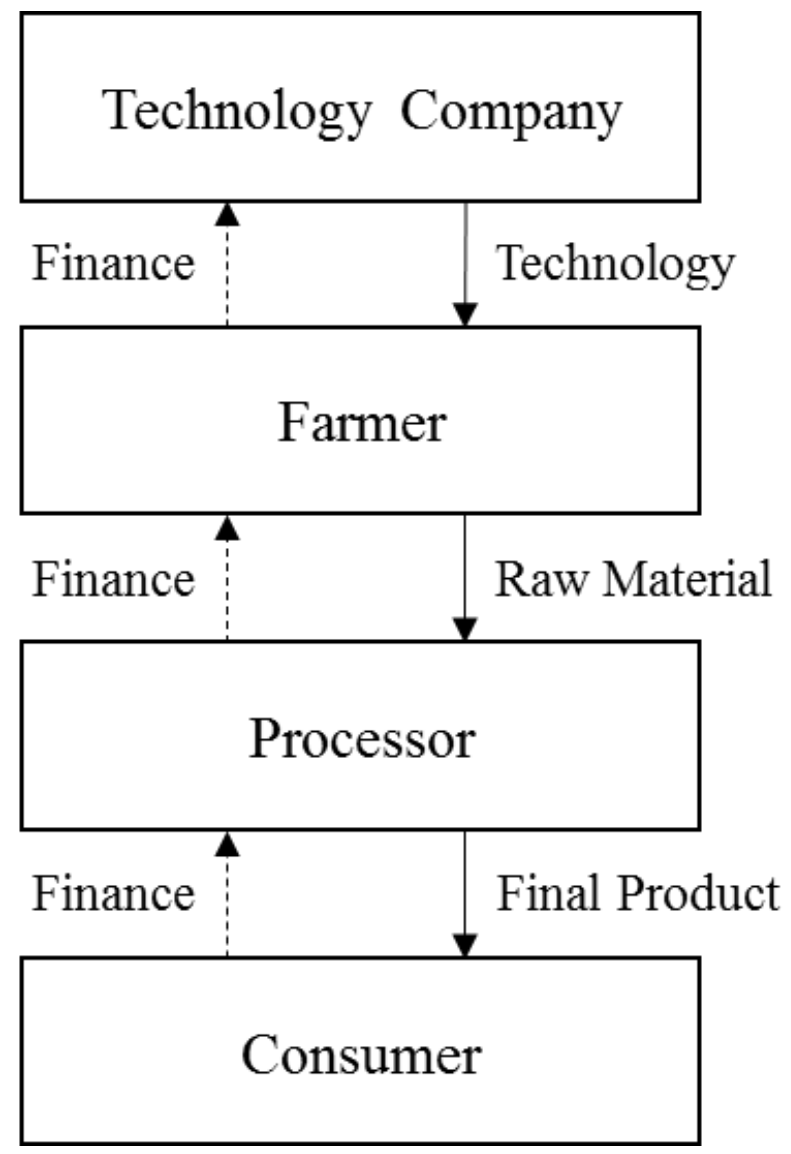


Figure 2: Farm - Processor Contracting

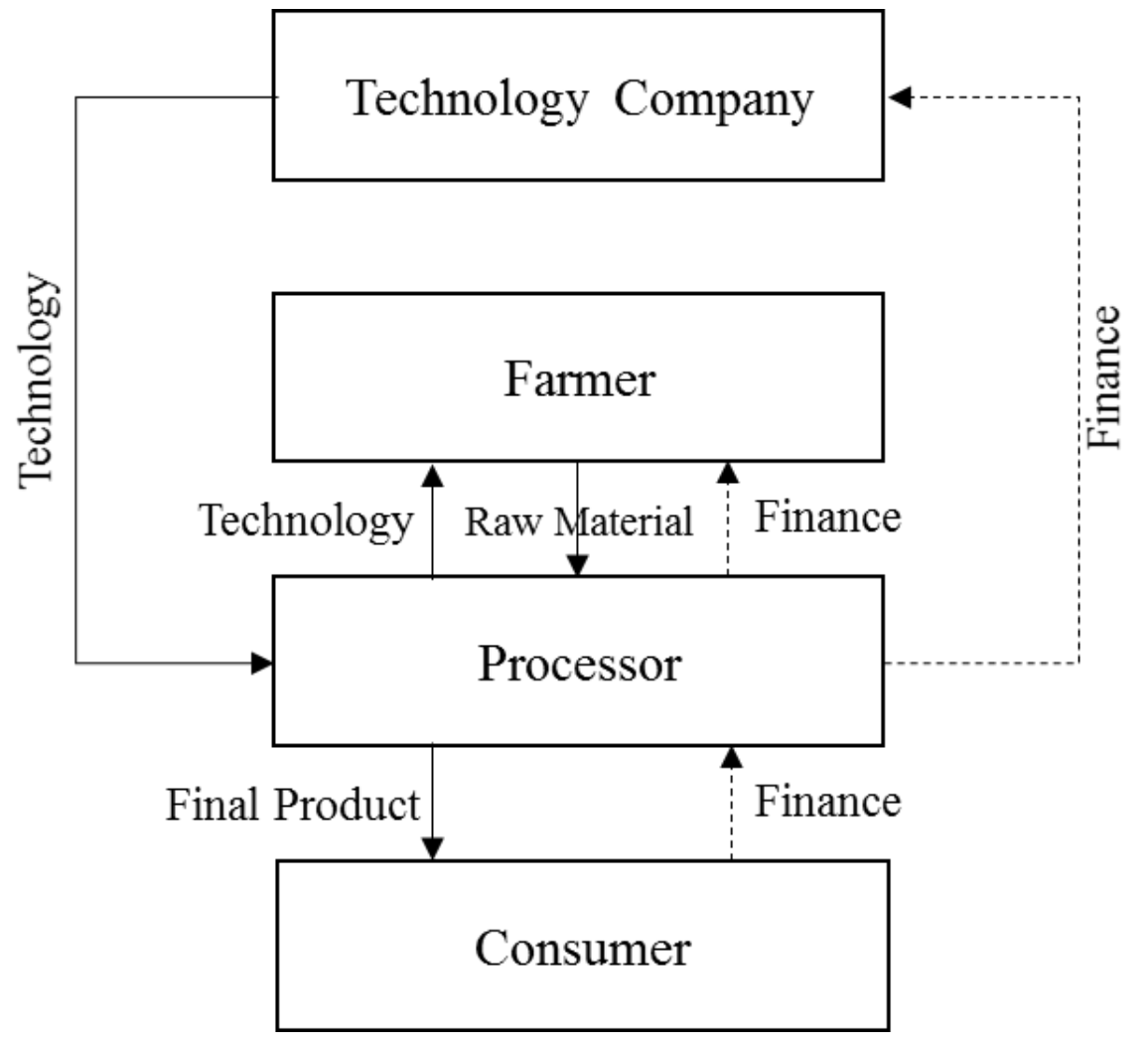


Figure 3: Multi-stage technology transfer in the brewing sector

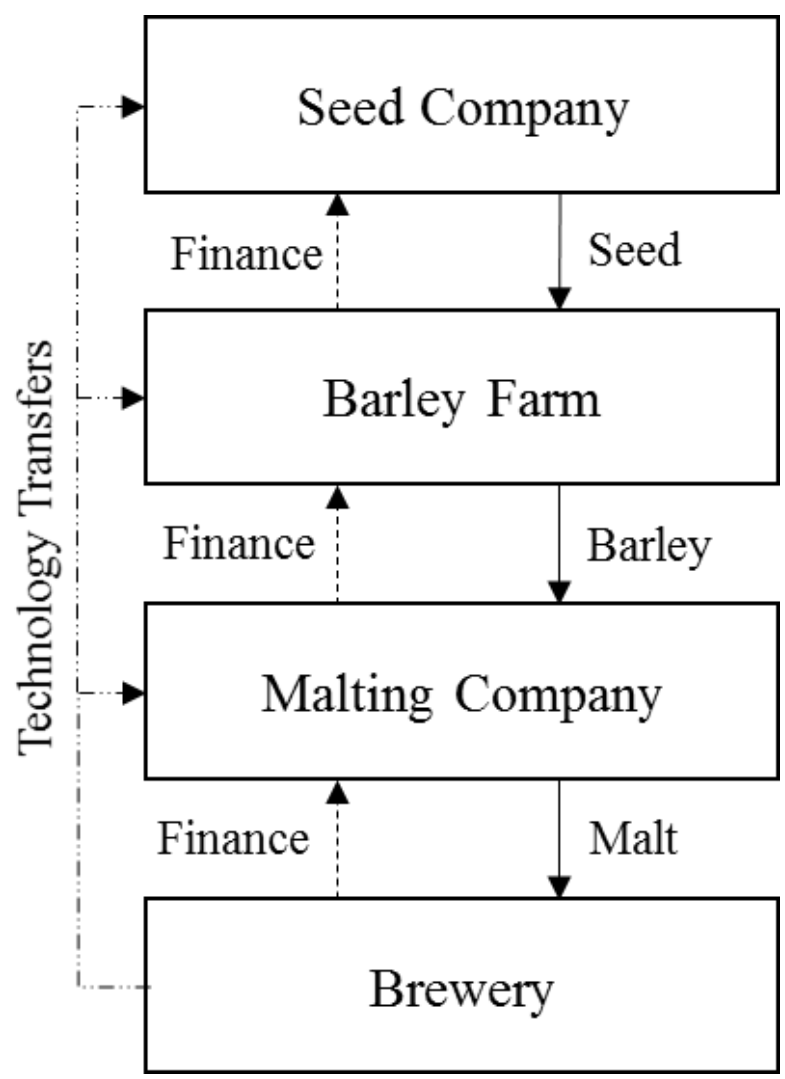


Figure 4: Farm - Technology Company Contracting

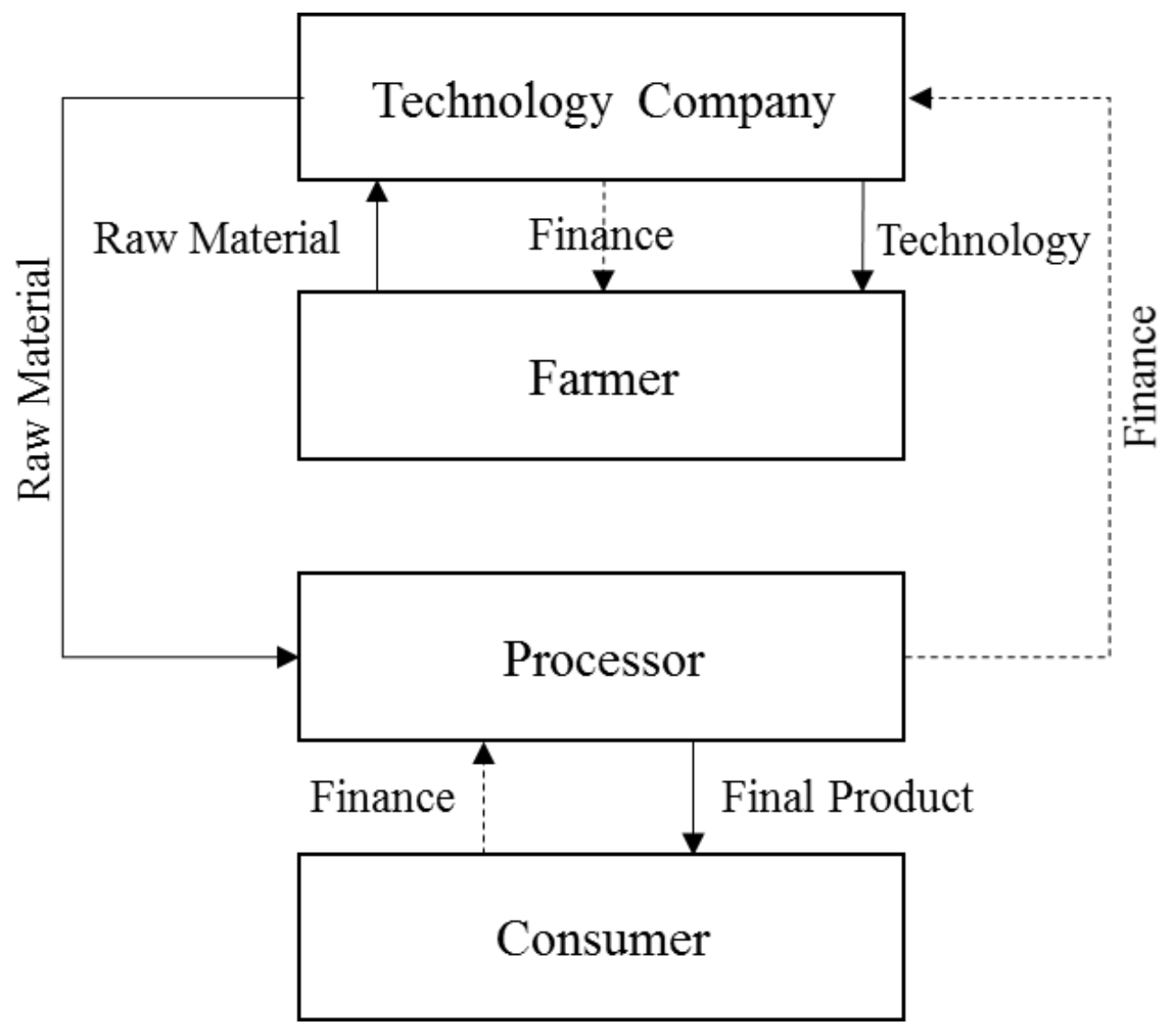


Figure 5: Triangular Value Chain Structure

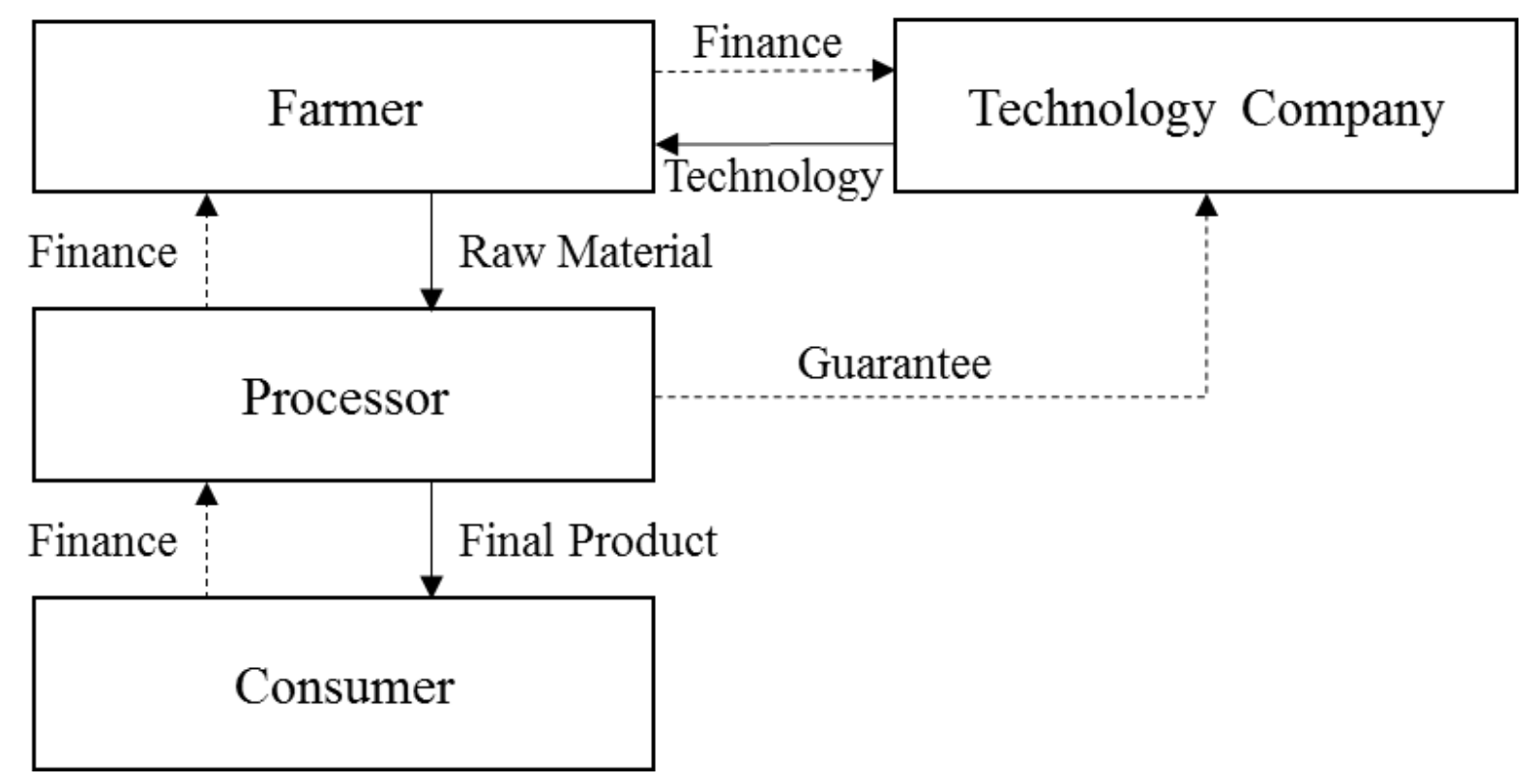


Figure 6: Special Purpose Vehicles for Technology Transfer

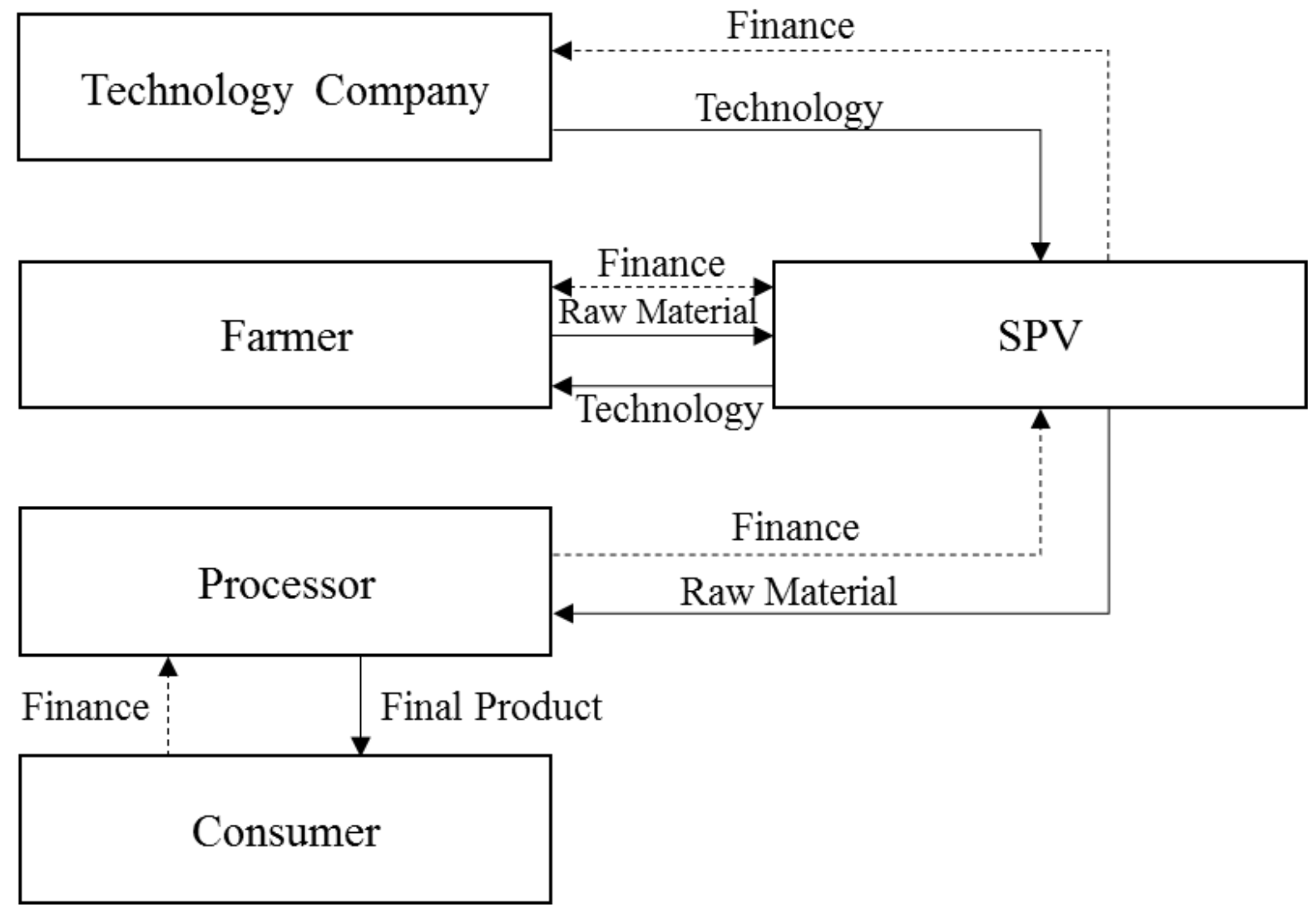




\begin{tabular}{|c|c|c|c|c|c|c|c|}
\hline Value Chain & 1. & 2. & 3. & 3. & 4. & 4. & 5. \\
\hline \multirow[t]{3}{*}{ Model } & Interlinked & Interlinked & Triangular & Triangular & Special & Special & Vertical \\
\hline & Contract & Contract & Structure & Structure & Purpose & Purpose & Integration \\
\hline & & & & & Vehicle & Vehicle & \\
\hline \multirow[t]{4}{*}{ Actors involved } & Processor & TechCo $^{\circ}$ & Processor & Processor & Processor & Processor & Processor \\
\hline & Farm & Farm & Bank & $\mathrm{TechCo}^{\circ}$ & $\mathrm{TechCo}^{\circ}$ & TechCo & Farm \\
\hline & & & Farm & Farm & Farm & ${ }^{\circ}$ Bank & \\
\hline & & & & & & Farm & \\
\hline \multicolumn{8}{|c|}{ Credit Constraints } \\
\hline Farm & Yes & Yes & Yes & Yes & Yes & Yes & Yes \\
\hline Processor & No & Yes & No & No & No & No & No \\
\hline Tech-Company & Yes & No & Yes & No & No & No & Yes \\
\hline Bank & Yes & Yes & No & Yes & Yes & No & Yes \\
\hline \multicolumn{8}{|c|}{ Type of Technology Transferred } \\
\hline $\begin{array}{l}\text { Time } \\
\text { Dimension }\end{array}$ & Short & Short & Long & Long & Long & Long & Long \\
\hline Specificity* & High & High & Low & Low & Low & Low & Low \\
\hline Land Access & No & No & No & No & No & No & Yes \\
\hline
\end{tabular}

* Assuming no complementary specific investments are made by the farmer.

${ }^{\circ}$ TechCo refers to technology company 
Table 2: Comparative Transaction Cost Advantages of Simple vs. Complex Institutional Solutions to Realize Technology Transfer

$\begin{array}{cc}\text { "Simple" Interlinked } & \text { "Complex" Multi-Agent } \\ \text { Contracting } & \text { Institutional Innovations }\end{array}$

(VC Models $1 \& 2$ )

(VC Models 3 \& 4)

\begin{tabular}{lll}
\hline Types of Transaction Costs & & \\
Governance set-up costs & Lower & Higher \\
Costs of Transfer & Higher & Lower \\
Monitoring and enforcement costs & Higher & Lower \\
Residual hold-up risk & & \\
$-\quad$ Farmer & Higher & Lower \\
$-\quad$ Among other VC actors & Lower & Higher \\
\hline
\end{tabular}

